\title{
eHealth and Telemedicine in India: An Overview on the Health Care Need of the People
}

\author{
Raj Kishor Kustwar ${ }^{1,2}$ and Suman Ray ${ }^{1,2^{*}}$ \\ ${ }^{1}$ CSIR-National Institute of Science Technology and Development Studies (NISTADS), New Delhi-110012, India \\ ${ }^{2}$ Academy of Scientific and Innovative Research (AcSIR), CSIR-Human Resource Development Centre, (CSIR-HRDC) \\ Campus, Ghaziabad, Uttar Pradesh-201002, India
}

*Email:suman@nistads.res.in

\section{ARTICLE INFORMATION}

Received: January 21, 2019

Revised: May 28, 2019

Accepted: July 30, 2020

Published Online: August 10, 2020

Keywords:

Telemedicine, eHealth, mHealth, Healthcare, GRAMSAT, EduSat, OncoNet

DOI: $10.15415 /$ jmrh.2020.62004

\section{ABSTRACT}

We have reached far ahead today when it comes to the telemedicine technology which was first installed in Boston in 1967 that made a regular interaction between physicians and patients at distant locations. Being a developing and lower-middle income country, currently India faces shortage of doctors, nurses \& midwives, and healthcare infrastructure. Around $70 \%$ of Indian population lives in remote and rural villages lacking access to basic healthcare facilities. In such situations telemedicine plays a great role in providing quality and affordable healthcare to India's poorest people, and is expected to bridge the rural-urban health divide. Whether telemedicine technology meets its objective to provide adequate healthcare services to the poor remote and rural population is matter of great concern. This article aims to provide an overview on this issue.

\section{Introduction}

India spends $3.8 \%$ of GDP (2015) on health which is far below other major countries like USA (16.83), Canada (10.43), UK (9.87), Brazil (8.91), Russia (5.56), China (5.3), Myanmar (4.94) but ahead of other countries like Indonesia (3.3), Laos (2.8) (Total expenditure on health as a percentage of Gross Domestic Product (GDP), 2015). Even the doctor's density per 1000 population in India is 0.6 which is also behind other major countries like USA (2.7), UK (2.1), Brazil (1.7), and China (1.4). In fact the global average of doctor density per 1000 population is 1.23 . Moreover, $70 \%$ of the Indian population lives in underserved rural areas, where only $2 \%$ doctors practice and most of them are registered medical practitioners (Patnaik \& Patnaik, 2015). While 23\% doctors practice in semi-urban areas and towns, and 75\% qualified doctors (specialists) practice in urban areas or in metro cities (Patnaik \& Patnaik, 2015). Thus, there exists a huge manpower gap in the health sector in India. In such a situation, emergence of telemedicine technology in India provides new possibilities to overcome the existing shortfalls in the healthcare sector. The first telemedicine center of India was opened by Apollo Hospital in Aragonda village of Chitto or District in Andhra Pradesh and it was connected to Apollo Hospital in Chennai through telemedicine. This first telemedicine center of India was inaugurated by then president of USA Mr. Bill Clinton. Since then, the Indian government is providing funds from time to time for the growth of the telemedicine facilities. The objective of the allocation of this money for telemedicine is to "access all the inaccessible parts" of the Indian subcontinent. Having low doctor to population ratio and low hospitals to population ratio, the telemedicine seems to be only possible and effective solution to overcome the current disease burden and mortality rate (Chandwani \& Dwivedi, 2015). The question arises whether telemedicine has really met its objectives of providing adequate and affordable healthcare to the country's poor population? The question is yet to be answered. 


\section{Recent Developments}

The government of India has taken many initiatives like National Medical College Network (NMCN)- to establish a national grid to connect medical colleges through high speed internet for medical education; National Rural Telemedicine Network (NRTN)- to design, develop and implement low cost telemedicine infrastructure in rural areas; and mHealth for covering entire country with telemedicine network to bestow rural peoples with tertiary healthcare facilities (Mishra et al., 2012). ISRO has played an imperative role in deployment of telemedicine services by providing satellite services through GRAMSAT, EduSat and INSAT satellites. Currently ISRO covers 384 telemedicine centers with 60 super specialty hospitals, Department of Information Technology (DIT) covers over 100 telemedicine nodes and OncoNet India project has been started by Ministry of Health and Family Welfare (MoH \& FW) to connect 108 Peripheral Cancer Centers (PCCs) with 27 Regional Cancer Centers (RCCs) (Mishra et al., 2012). The Karnataka Internet-Assisted Diagnosis of Retinopathy of Prematurity (KIDROP) and the Revised National Tuberculosis Control Program (RNTCP) have been initiated to cure diabetic retinopathy and tuberculosis respectively, in both urban and rural partsof the country (Sheet, 2016). Government of Andhra Pradesh has started MukhyaMantri e-Eye Kendram under National Health Mission (NHM) to provide teleophthalmology services to the people (MukhyaMantri e-Eye Kendram Web Portal, 2019). Currently teleophthalmology services are being provided from 116 Active Centers of MukhyaMantri e-Eye Kendram, and more than 975000 people have visited these centers for their treatment (MukhyaMantri e-Eye Kendram Web Portal, 2019). Government of Andhra Pradesh has also started MukhyaMantri Aarogya Kendra mulu under NHM to provide healthcare services to the people through telemedicine, and more than 38000 teleconsultations have been provided till date through these centers (MukhyaMantri Aarogya Kendramulu Web Portal, 2019).

Schizophrenia Research Foundation (SCARF) has started telemedicine services in rural Tamil Nadu in year 2005, currently it is providing telepsychiatry services to 156 villages covering around 300000 people (SCARF Web Portal, 2019). Further, Madras Diabetes Research Foundation (MDRF) has started Chunampet Rural Diabetes Prevention Project (CRDPP) to provide telemedicine services to rural patients suffering from diabetes (MDRF Web Portal, 2019); Mohan et al., 2014). Telemedicine services at National Institute of Mental Health Sciences (NIMHANS), Bangalore have been started in the year 2001; upto 2014 NIMHANS has provided 755 teleconsultations in psychiatry, 215 in neurology, 93 in neurosurgery and 206 in other medical specialties (NIMHANS Telemedicine Web
Portal, 2019). Postgraduate Institute of Medical Education $\&$ Research (PGIMER), Chandigarh is also a leading telemedicine service provider in psychiatry as well as in other medical specialties (PGIMER, Chandigarh Telemedicine Web Portal, 2019). PGIMER Chandigarh has also been made Regional Resource Center of Telemedicine for North India under NMCN (National Telemedicine portal, Telemedicine Division, Ministry of Health and Family Welfare, Government of India, 2019). Currently India has more than 600 telemedicine centers widely distributed across diverse geographic and socioeconomic settings (Figure 1 and Table 1). Table 2 describes about the eHealth and mHealth systems developed for better Healthcare Delivery across India.

\section{Telemedicine: Is it an Alternative Option for Conventional Face to Face Consultation?}

A cross-sectional study has revealed the satisfaction for telemedicine among $80 \%$ patients and all the doctors on the basis of evaluation of perception of patients and doctors towards the use of telemedicine at Apollo Tele Health Services (Acharya \& Rai, 2016). Additionally, 90\% of the participants have found telemedicine to be cost-effective and $61 \%$ of the doctors who have participated in the survey have found an increase in inflow of patients apart from the regular number of patient's visits (Acharya \& Rai, 2016). Besides these advantages there are several major concerns that hinders the complete use of telemedicine. For example,

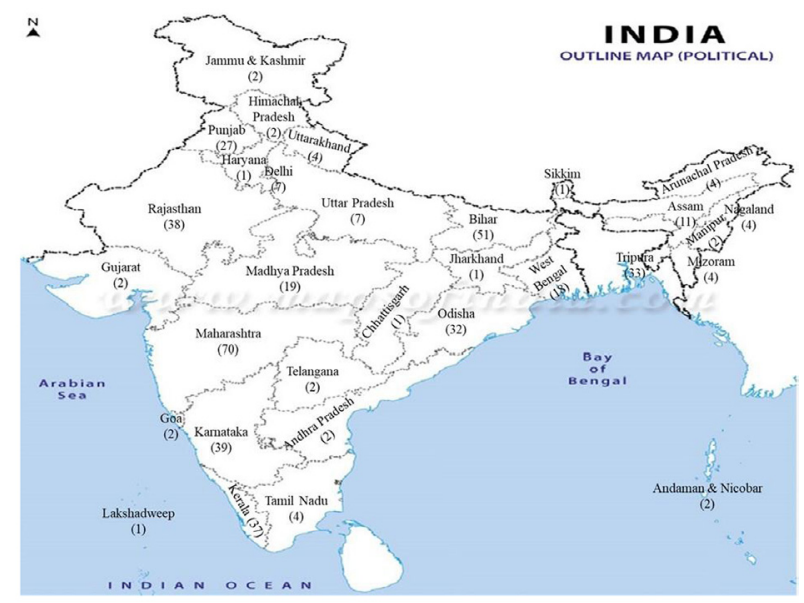

Figure 1: Distribution of Telemedicine Centers in Indian States and Union Territories; No. of telemedicine centers in each state is indicated against name of each state (Mishra et al., 2012; (National Telemedicine portal, 2019; Telemedicine Division Ministry of Health and Family Welfare, Government of India, 2019; SGPGIMS Lucknow Telemedicine Web Portal, 2019; National Health Portal of India, Government of India, 2019); Mathur et al., 2017; Ray et al., 2017). 
Table 1: Illustration of Private Telemedicine Service Providers in India (Mishra et al., 2012; Ray et al., 2017; Aravind Eye Care System Web Portal; Venu Eye Institute \& Research Center Web Portal; Welcare Telemedicine Web Portal; Ramkumar \& Selvakumar, 2016; India Vision Institute Web Portal, 2019).

\begin{tabular}{|c|c|c|c|}
\hline $\begin{array}{l}\text { S. } \\
\text { No. }\end{array}$ & $\begin{array}{c}\text { Name of the } \\
\text { Institute/Hospital }\end{array}$ & Specialty & $\begin{array}{l}\text { No. of } \\
\text { Nodes }\end{array}$ \\
\hline 1 & $\begin{array}{l}\text { Amrita Institute } \\
\text { Medical of Sciences } \\
\text { (AIMS), Kochi }\end{array}$ & Multi-Specialty & 69 \\
\hline 2 & $\begin{array}{l}\text { Apollo Group of } \\
\text { Hospitals }\end{array}$ & $\begin{array}{l}\text { Multi-Specialty } \\
\text { and Developed } \\
\text { "Medintegra" } \\
\text { software for } \\
\text { telemedicine services }\end{array}$ & 150 \\
\hline 3 & $\begin{array}{l}\text { Asia Heart } \\
\text { Foundation } \\
\text { (Bengaluru and } \\
\text { Mumbai) }\end{array}$ & Telecardiology & 02 \\
\hline 4 & $\begin{array}{l}\text { Fortis Group of } \\
\text { Hospitals }\end{array}$ & Multi-Specialty & 20 \\
\hline 5 & NarayanaHrudayalaya & Telecardiology & 26 \\
\hline 6 & $\begin{array}{l}\text { Dr. Balabhai Nanavati } \\
\text { Hospital, Mumbai }\end{array}$ & Multi-Specialty & 32 \\
\hline 7 & $\begin{array}{l}\text { Escorts Heart Institute } \\
\text { and Research Center }\end{array}$ & Telecardiology & 08 \\
\hline 8 & Shankara Netralaya & Teleophthalmology & 50 \\
\hline 9 & $\begin{array}{l}\text { Aravind eye care } \\
\text { systems }\end{array}$ & Ophthalmology & 61 \\
\hline 10 & $\begin{array}{l}\text { Venu Eye Institute } \\
\text { and Research center }\end{array}$ & Ophthalmology & 13 \\
\hline 11 & $\begin{array}{l}\text { WELCARE Health } \\
\text { systems }\end{array}$ & Ophthalmology & 160 \\
\hline 12 & $\begin{array}{l}\text { Sri Ramchandra } \\
\text { Hospital, Chennai }\end{array}$ & Multi-Specialty & 31 \\
\hline 13 & India vision Institute & Ophthalmology & $\begin{array}{c}105 \\
\text { Programs }\end{array}$ \\
\hline
\end{tabular}

in case of diagnosis and surgery by using telemedicine, same quality of care as compared to conventional face to face care is not possible. Studies have shown that, despite having positive teleconsultations patients felt that telemedicine cannot be alternative to conventional face to face consultation (Meher $\&$ Kant, 2014). Others have demonstrated that out of 114 patients interviewed, 43 respondents said that telemedicine cannot replace face to face consultation and 14 said that they could not rely on tele-consultation (Meher et al., 2009). Also it has been shown that out of 115 patients 56 did not feel comfortable during teleconsultation and 77 said that their privacy was not maintained during teleconsultations done at Himalayan Institute Hospital Trustin Uttarakhand (Suresh $\&$ Nath, 2013). Sometimes the doctor needs to analyze the patient by putting his/her hand on patient (or by observing patient physically), in such a situation telemedicine approach becomes limiting. Even if the doctors prescribe a particular medicine to the patients via tele-consultation, it becomes difficult to access the medicine in remote areas of the country due to their non-availability (Ganapathy et al., 2016). How do the patients help themselves in such a situation besides having telemedicine facilities in these remote areas? Even now a days the patients in remote areas have to travel miles from their home (or village) for reaching the teleconsultation facility. More focused approach towards telemedicine is needed so that they patients need not to travel much for availing telemedicine services. In addition, although several evidences indicate telemedicine to be cost-effective, this might not be affordable for the poorest of the poor in India. Telemedicine in fact may be considered complimentary to fulfill healthcare need ofthe poor. Thus, the Indian government needs to recognize the factors hampering utilization of telemedicine along with its limitations.

\section{Policy Majors Taken for Telemedicine Development, Deployment and Promotion}

To strengthen the e-health and Telemedicine services and to empower people with better healthcare services Government of India has framed and implemented many policies from time to time. The major policy initiatives taken for telemedicine in India are described below:

1. "National Standards on Telemedicine" have been notified in 2003, "National Steering Committee on Telemedicine under constituted in 2005" and "National Standards for Electronic Health Records (EHR)/ Electronic Medical Records (EMR)" have been drafted during the period of 2010 to 2013 (Telemedicine National Policies, Strategies and Guidelines for implementation, 2019).

2. To standardize telemedicine platform and services, Department of Information Technology, under Ministry of Communication and Information Technology, Government of India has framed a document named "Recommended Guidelines and Standards for Practice of telemedicine in India" and has been released in the year 2003. This document focuses on interoperability of telemedicine services and to assist various telemedicine implementing agencies in the planning and implementation of various telemedicine networks across the country (Mishra et al., 2012). 
Table 2: eHealth and mHealth systems developed for better Healthcare Delivery across Country.

\begin{tabular}{|c|c|c|c|c|c|}
\hline $\begin{array}{l}\text { S. } \\
\text { No. }\end{array}$ & System & Initiator & Services & $\begin{array}{l}\text { Deployment } \\
\text { Location }\end{array}$ & Reference \\
\hline \multicolumn{6}{|c|}{ eHealth Systems developed for remote medical consultation (teleconsultations) } \\
\hline 1 & E-Clinic & Nandi Foundation & $\begin{array}{l}\text { This system provides medical } \\
\text { teleconsultations and healthcare services to } \\
\text { cancer patients }\end{array}$ & Malwa, Punjab & $\begin{array}{l}\text { Sharma } \\
\text { et al., } 2016\end{array}$ \\
\hline 2 & Health NET & 21 Century & $\begin{array}{l}\text { This system delivers quality healthcare } \\
\text { services to all segments of society including } \\
\text { poor people living in remote areas }\end{array}$ & Goa & $\begin{array}{l}\text { Sharma } \\
\text { et al., } 2016\end{array}$ \\
\hline 3 & $\begin{array}{l}\text { Child Health } \\
\text { Monitoring } \\
\text { System }\end{array}$ & Intel & $\begin{array}{l}\text { This system provides checkup facilities and } \\
\text { diagnostic services to needy children living } \\
\text { in urban areas }\end{array}$ & $\begin{array}{l}\text { Chandani Chowk, } \\
\text { New Delhi }\end{array}$ & $\begin{array}{l}\text { Sharma } \\
\text { et al., } 2016\end{array}$ \\
\hline 4 & $\begin{array}{l}\text { Hello Doctor } \\
24^{*} 7\end{array}$ & $\begin{array}{l}\text { MKCG Medical } \\
\text { College, } \\
\text { Orissa }\end{array}$ & $\begin{array}{l}\text { Provide healthcare information to rural } \\
\text { public in form of teleconsultation }\end{array}$ & Odisha & $\begin{array}{l}\text { Sharma } \\
\text { et al., } 2016\end{array}$ \\
\hline 5 & $\begin{array}{l}\text { School Health } \\
\text { Monitoring } \\
\text { System } \\
\end{array}$ & $\begin{array}{l}\text { Tata Consultancy } \\
\text { Services and Intel }\end{array}$ & $\begin{array}{l}\text { Provides health education and learning to } \\
\text { teachers and students of the school }\end{array}$ & $\begin{array}{l}\text { St. Philomena Girls } \\
\text { Higher School, } \\
\text { Trivandrum } \\
\end{array}$ & $\begin{array}{l}\text { Sharma } \\
\text { et al., } 2016\end{array}$ \\
\hline 6 & $\begin{array}{l}\text { HealthCare } \\
\text { Solution } \\
\end{array}$ & Hewlett Packard & $\begin{array}{l}\text { This system has been designed for patient's } \\
\text { management }\end{array}$ & Maharashtra & $\begin{array}{l}\text { Sharma } \\
\text { et al., } 2016\end{array}$ \\
\hline 7 & Neonatology & $\begin{array}{l}\text { All India Institute of } \\
\text { Medical } \\
\text { Sciences (AIIMS) }\end{array}$ & $\begin{array}{l}\text { This system has been designed to provide } \\
\text { critical information to healthcare } \\
\text { professionals regarding care of newborn }\end{array}$ & Global & $\begin{array}{l}\text { Sharma } \\
\text { et al., } 2016\end{array}$ \\
\hline 8 & Telemedicine & $\begin{array}{l}\text { Government of } \\
\text { India, } \\
\text { Apollo Telemedicine } \\
\text { Networking } \\
\text { Foundation } \\
\text { (ATNF) } \\
\end{array}$ & $\begin{array}{l}\text { This system has been designed for sharing } \\
\text { of knowledge among doctors in course } \\
\text { of treatment, for sharing of equipment/ } \\
\text { medical tools. It can also be used to } \\
\text { provide healthcare training to healthcare } \\
\text { personals or ground staff at distant places }\end{array}$ & $\begin{array}{l}\text { Uttaranchal, Uttar } \\
\text { Pradesh, Orissa and } \\
\text { Karnataka }\end{array}$ & $\begin{array}{l}\text { Sharma } \\
\text { et al., } 2016\end{array}$ \\
\hline 9 & $\begin{array}{l}\text { Virtual Medical } \\
\text { Kiosk }\end{array}$ & $\begin{array}{l}\text { E-Health Access } \\
\text { Private Limited }\end{array}$ & $\begin{array}{l}\text { This system has been designed to provide } \\
\text { secure and safe environment to doctors and } \\
\text { patients for medical consultation }\end{array}$ & $\begin{array}{l}\text { Hyderabad and } \\
\text { Andhra Pradesh }\end{array}$ & $\begin{array}{l}\text { Sharma } \\
\text { et al., } 2016\end{array}$ \\
\hline \multicolumn{6}{|c|}{ eHealth systems designed for the purpose of training and learning } \\
\hline 10 & Newborn Care & $\begin{array}{l}\text { World Health } \\
\text { Organization } \\
\text { (WHO) and } \\
\text { AIIMS }\end{array}$ & $\begin{array}{l}\text { It has been designed to provide e-Learning } \\
\text { facilities to healthcare professionals and } \\
\text { healthcare workers }\end{array}$ & Global & $\begin{array}{l}\text { Sharma } \\
\text { et al., } 2016\end{array}$ \\
\hline \multicolumn{6}{|c|}{ eHealth systems designed and developed for hospital and record management } \\
\hline 11 & $\begin{array}{l}\text { Hospital } \\
\text { Information } \\
\text { System (HIS) }\end{array}$ & Wipro & $\begin{array}{l}\text { This system has been developed for } \\
\text { providing services such as registration } \\
\text { of patients, digitalization of patient's } \\
\text { healthcare data, hospital record } \\
\text { management etc. }\end{array}$ & $\begin{array}{l}\text { Six hospitals of Delhi } \\
\text { Municipal } \\
\text { Corporation }\end{array}$ & $\begin{array}{l}\text { Sharma } \\
\text { et al., } 2016\end{array}$ \\
\hline 12 & $\begin{array}{l}\text { India HealthCare } \\
\text { Projects }\end{array}$ & $\begin{array}{l}\text { Computer } \\
\text { Management } \\
\text { Corporation(CMC) } \\
\text { Ltd. }\end{array}$ & $\begin{array}{l}\text { This system facilitate the user with } \\
\text { compilation of healthcare data and } \\
\text { generation of reports }\end{array}$ & Andhra Pradesh & $\begin{array}{l}\text { Sharma } \\
\text { et al., } 2016\end{array}$ \\
\hline 13 & $\begin{array}{l}\text { Electronic } \\
\text { Medical } \\
\text { Record (EMR) }\end{array}$ & $\begin{array}{l}\text { Tata Consultancy } \\
\text { Services } \\
\text { and Intel }\end{array}$ & $\begin{array}{l}\text { Collect and saves medical records of } \\
\text { patients. Provides medical history of } \\
\text { patients }\end{array}$ & Tamil Nadu & $\begin{array}{l}\text { Sharma } \\
\text { et al., } 2016\end{array}$ \\
\hline
\end{tabular}


Table 2. Continued.

\begin{tabular}{|c|c|c|c|c|c|}
\hline $\begin{array}{l}\text { S. } \\
\text { No. }\end{array}$ & System & Initiator & Services & $\begin{array}{l}\text { Deployment } \\
\text { Location }\end{array}$ & Reference \\
\hline 14 & $\begin{array}{l}\text { Individual } \\
\text { Tracking } \\
\text { and Record } \\
\text { Management } \\
\text { System }\end{array}$ & $\begin{array}{l}\text { Institute of Electrical } \\
\text { and Electronics } \\
\text { Engineers (IEEE) }\end{array}$ & $\begin{array}{l}\text { Maintains the history of infants and } \\
\text { Vaccination }\end{array}$ & Ahmadabad & $\begin{array}{l}\text { Sharma } \\
\text { et al., } 2016\end{array}$ \\
\hline \multicolumn{6}{|c|}{ Online web portals for healthcare delivery and information and tracking } \\
\hline 15 & $\begin{array}{l}\text { National Health } \\
\text { Portal (NHP) }\end{array}$ & MoH\&FW & $\begin{array}{l}\text { It serves as a single point of authentic and } \\
\text { reliable healthcare information access to } \\
\text { citizens, students, healthcare professionals, } \\
\text { researchers and policy makers }\end{array}$ & $\begin{array}{l}\text { All over India } \\
\text { Toll free helpline no.- } \\
1800-180-1104\end{array}$ & $\begin{array}{l}\text { (National } \\
\text { Health Portal } \\
\text { of India, } \\
\text { Government of } \\
\text { India, 2019) }\end{array}$ \\
\hline 16 & $\begin{array}{l}\text { Online } \\
\text { Registration } \\
\text { System (ORS) }\end{array}$ & $\mathrm{MoH} \& \mathrm{FW}$ & $\begin{array}{l}\text { Offers services for online registration, } \\
\text { payment of fee and appointment, enquiry } \\
\text { of blood availability and online diagnostic } \\
\text { reports }\end{array}$ & All over India & $\begin{array}{l}\text { (Online } \\
\text { Registration } \\
\text { System Web } \\
\text { Portal, 2019) } \\
\end{array}$ \\
\hline 17 & $\begin{array}{l}\text { National Organ } \\
\text { and Tissue } \\
\text { Transplant } \\
\text { Organisation } \\
\text { (NOTTO) }\end{array}$ & $\mathrm{MoH} \& \mathrm{FW}$ & $\begin{array}{l}\text { Avail users with } \\
\text { Online organ donor pledge, } \\
\text { Online hospital registration for Organ/ } \\
\text { Tissue Transplant or Retrieval }\end{array}$ & $\begin{array}{l}\text { Located at VMMC } \\
\text { and Safdarjung } \\
\text { Hospital, New Delhi }\end{array}$ & $\begin{array}{l}\text { (NOTTO Web } \\
\text { Portal, 2019) }\end{array}$ \\
\hline 18 & $\begin{array}{l}\text { Central Drug } \\
\text { Standard Control } \\
\text { Organisation } \\
\text { (CDSCO) } \\
\end{array}$ & MoH\&FW & $\begin{array}{l}\text { CDSCO has been made online through } \\
\text { use of software "SUGAM" to avail users } \\
\text { with associated facilities }\end{array}$ & New Delhi & $\begin{array}{l}\text { (CDSCO Web } \\
\text { Portal, 2019) }\end{array}$ \\
\hline 19 & Nikshay & $\mathrm{MoH} \& \mathrm{FW}$ & $\begin{array}{l}\text { Nikshay is case based and web based } \\
\text { application software for online monitoring } \\
\text { of TB patients }\end{array}$ & All over India & $\begin{array}{l}\text { (Nikshay Web } \\
\text { Portal, 2019) }\end{array}$ \\
\hline 20 & $\begin{array}{l}\text { Health } \\
\text { Information } \\
\text { Management } \\
\text { System (HMIS) }\end{array}$ & MoH\&FW & $\begin{array}{l}\text { It is a web based portal designed and } \\
\text { developed for monitoring the programs } \\
\text { running under National Health Mission; It } \\
\text { compiles data from district level and state } \\
\text { level authorities, district level household } \\
\text { survey, national family health survey. } \\
\text { Around } 2 \text { lacs health facilities uploading } \\
\text { monthly data on performance, and it is } \\
\text { also integrated with Global Information } \\
\text { System (GIS) }\end{array}$ & All over India & $\begin{array}{l}\text { (HMIS Web } \\
\text { Portal, 2019) }\end{array}$ \\
\hline 21 & $\begin{array}{l}\text { Integrated Health } \\
\text { Information } \\
\text { Platform (IHIP) }\end{array}$ & $\mathrm{MoH} \& \mathrm{FW}$ & $\begin{array}{l}\text { MoH\&FW is in process for setting } \\
\text { up IHIP with a view to establishing a } \\
\text { Pan-India integrated health information } \\
\text { system along with online Electronic Health } \\
\text { Record (EHR) and health information } \\
\text { exchange }\end{array}$ & Pan-India & $\begin{array}{l}\text { (IHIP Web } \\
\text { Portal, 2019) }\end{array}$ \\
\hline \multicolumn{6}{|c|}{ Mobile based application for better healthcare awareness and services } \\
\hline 22 & $\begin{array}{l}\text { mCessation (Quit } \\
\text { tobacco) }\end{array}$ & $\mathrm{MoH} \& \mathrm{FW}$ & $\begin{array}{l}\text { This is a program in partnership } \\
\text { with WHO and International } \\
\text { telecommunication Union (ITU) for } \\
\text { helping people in quitting tobacco by } \\
\text { continuous messaging }\end{array}$ & $\begin{array}{l}\text { All over India } \\
\text { Telephone No.- } 011 \text { - } \\
22901701\end{array}$ & $\begin{array}{l}\text { (mCessation } \\
\text { Programme } \\
\text { Quit Tobacco } \\
\text { for Life, 2019) }\end{array}$ \\
\hline
\end{tabular}


Table 2. Continued.

\begin{tabular}{|c|c|c|c|c|c|}
\hline $\begin{array}{l}\text { S. } \\
\text { No. }\end{array}$ & System & Initiator & Services & $\begin{array}{l}\text { Deployment } \\
\text { Location }\end{array}$ & Reference \\
\hline 23 & mDiabetes & $\mathrm{MoH} \& \mathrm{FW}$ & $\begin{array}{l}\text { This is an initiative taken by } \mathrm{MoH} \& \mathrm{FW} \\
\text { for prevention and care of diabetes }\end{array}$ & $\begin{array}{l}\text { All over India } \\
\text { Telephone No.- } 011 \text { - } \\
22901701\end{array}$ & $\begin{array}{l}\text { (Ministry of } \\
\text { Health and } \\
\text { Family Welfare, } \\
\text { 2019) }\end{array}$ \\
\hline 24 & Swasthya Bharat & MoH\&FW & $\begin{array}{l}\text { This is the mobile application that } \\
\text { empowers the users with the following } \\
\text { services:- } \\
\text { Detailed information regarding healthy } \\
\text { lifestyle, } \\
\text { Information about condition of Disease in } \\
\text { alphabetical order (A-Z), including } \\
\text { Symptoms, treatment strategies/options } \\
\text { and First aid. It also empowers users with } \\
\text { public health alert }\end{array}$ & All over India & $\begin{array}{l}\text { (Swasthya } \\
\text { Bharat Portal, } \\
\text { 2019) }\end{array}$ \\
\hline 25 & $\begin{array}{l}\text { India Fights } \\
\text { Dengue }\end{array}$ & $\mathrm{MoH} \& \mathrm{FW}$ & $\begin{array}{l}\text { This app provides interactive information } \\
\text { to the users for identification of dengue } \\
\text { fever, symptoms of dengue fever. It also } \\
\text { provides the links of the nearest hospitals } \\
\text { and blood banks to the users }\end{array}$ & All over India & $\begin{array}{l}\text { (National Health } \\
\text { Portal Gateway } \\
\text { of Authentic } \\
\text { Health } \\
\text { Information, } \\
\text { 2019) }\end{array}$ \\
\hline 26 & MeraAspatal & $\mathrm{MoH} \& \mathrm{FW}$ & $\begin{array}{l}\text { It is an initiative of MoH\&FW for taking } \\
\text { feedback on the services received from both } \\
\text { private and public healthcare providers } \\
\text { (e.g. Hospitals) }\end{array}$ & All over India & $\begin{array}{l}\text { (My Hospital } \\
\text { Ministry } \\
\text { of Health, } \\
\text { Government of } \\
\text { India, 2019) }\end{array}$ \\
\hline 27 & $\begin{array}{l}\text { Vaccine Tracker } \\
\text { (Indradhanush } \\
\text { Immunisation) }\end{array}$ & MoH\&FW & $\begin{array}{l}\text { This app helps parents for tracking their } \\
\text { children's immunization status }\end{array}$ & All over India & $\begin{array}{l}\text { (Indradhanush } \\
\text { Immunization, } \\
\text { NHP, 2019) }\end{array}$ \\
\hline 28 & Kilkari & $\mathrm{MoH} \& \mathrm{FW}$ & $\begin{array}{l}\text { This initiative has been taken for increasing } \\
\text { awareness about pregnancy, child birth and } \\
\text { child care in women community. Under this } \\
72 \text { audio messages are being delivered free of } \\
\text { cost in time appropriate manner on weekly } \\
\text { basis. Toll free No.- 1800-3010-1703 }\end{array}$ & $\begin{array}{l}\text { Jharkhand, Odisha, } \\
\text { UP, MP, Uttarakhand } \\
\text { and Rajasthan }\end{array}$ & $\begin{array}{l}\text { (KKMSG Web } \\
\text { Portal, 2019) }\end{array}$ \\
\hline 29 & $\begin{array}{l}\text { ANM on-Line } \\
\text { (ANMOL) }\end{array}$ & $\mathrm{MoH} \& \mathrm{FW}$ & $\begin{array}{l}\text { It is a tablet based application that aims to } \\
\text { bring better healthcare services and better } \\
\text { consultation to pregnant women, mothers } \\
\text { and newborns }\end{array}$ & Pan-India & $\begin{array}{l}\text { (ANMOL Web } \\
\text { Portal, 2019) }\end{array}$ \\
\hline \multicolumn{6}{|c|}{ Private online web portals/apps providing healthcare services } \\
\hline 30 & Televital & Televital & $\begin{array}{l}\text { Provides telemedicine services to } 400+ \\
\text { hospitals in India. They have also partnered } \\
\text { with ISRO to provide telemedicine and } \\
\text { eHealth services to remotest parts of the } \\
\text { country. We have initiator of anesthesia } \\
\text { monitoring through telemedicine. }\end{array}$ & $\begin{array}{l}\text { Remotest villages } \\
\text { of North-East, } \\
\text { Andaman \& } \\
\text { Nicobar Islands, } \\
\text { Andhra Pradesh and } \\
\text { Karnataka etc. }\end{array}$ & $\begin{array}{l}\text { (Televital- } \\
\text { Enhancing the } \\
\text { Quality of Life, } \\
\text { Web Portal, } \\
\text { 2019) }\end{array}$ \\
\hline 31 & AskApollo & $\begin{array}{l}\text { Apollo Group of } \\
\text { Hospitals }\end{array}$ & $\begin{array}{l}\text { This platform facilitates the users to book } \\
\text { online appointments for consultation, } \\
\text { diagnosis, health checkup etc. in almost all } \\
\text { the hospitals of Apollo group distributed } \\
\text { in India. }\end{array}$ & $\begin{array}{l}\text { All major metro cities } \\
\text { in India }\end{array}$ & $\begin{array}{l}\text { (AskApollo Web } \\
\text { Portal, 2019) }\end{array}$ \\
\hline
\end{tabular}


Table 2. Continued.

\begin{tabular}{|l|l|l|l|l|l|}
\hline $\begin{array}{l}\text { S. } \\
\text { No. }\end{array}$ & System & Initiator & Services & $\begin{array}{l}\text { Deployment } \\
\text { Location }\end{array}$ & Reference \\
\hline 32 & Practo & Practo & $\begin{array}{l}\text { This facilitates users to book online } \\
\text { appointment with doctors, diagnostic tests, } \\
\text { health checkups and medicines }\end{array}$ & All over India & $\begin{array}{l}\text { (Practo Web } \\
\text { Portal, 2019) }\end{array}$ \\
\hline 33 & Portea & Portea Heal at home & $\begin{array}{l}\text { This provides hospital quality services } \\
\text { at home. It also facilitates users to book } \\
\text { online appointment with doctors, } \\
\text { diagnostic tests, health checkups etc. }\end{array}$ & $\begin{array}{l}\text { Almost all major } \\
\text { metro cities in India }\end{array}$ & $\begin{array}{l}\text { (Portea Web } \\
\text { Portal, 2019) }\end{array}$ \\
\hline 34 & Lybrate & Lybrate & $\begin{array}{l}\text { Provides medical advice. Facilitates users to } \\
\text { book online appointments for consultation } \\
\text { and lab test }\end{array}$ & All over India & $\begin{array}{l}\text { (Lybrate Web } \\
\text { Portal, 2019) }\end{array}$ \\
\hline 35 & Doctor INSTA & Doctor INSTA & $\begin{array}{l}\text { Facilitate the users with instant } \\
\text { consultation with doctors and specialist }\end{array}$ & All over India & $\begin{array}{l}\text { (Doctor INSTA } \\
\text { Web Portal, } \\
2019)\end{array}$ \\
\hline
\end{tabular}

3. "The framework for Information Technology Infrastructure for Health" has been prepared by DIT for addressing the information needs of people (Mishra et al., 2012).

4. "National Task Force on Telemedicine" has been set up by MoH\&FW, Government of India in 2005 to fulfill multiple objectives of telemedicine and eHealth, such as to resolve interoperability issues, to define national telemedicine grid, to prepare pilot projects for connectivity of hospitals, to prepare curriculum and projects for Continuing Medical Education (CME), and most importantly drafting of a national policy for "Telemedicine and Telemedical Education" (Mishra et al., 2012).

5. MoH \& FW has notified EHR standards for country with a view to their requirement and applicability in country. These were supported by major telemedicine providers and stakeholders (EHR Standards for India, Government of India, 2019).

6. MoH\&FW has also led initiative to constitute "National Digital Health Authority (NDHA)" in National Health Policy 2017. NDHA will act as promotional, regulatory and standard setting organisation for eHealth and Telemedicine in India (National Health Policy Government of India, 2017).

\section{Challenges and Barriers}

About 75\% doctors in Kangra District of Himachal Pradesh (HP) revealed that hospitals lack diagnostics facilities for Acute Myocardial Infarction (AMI) and 94\% agreed to the fact that Telecardiology services can improve healthcare services for AMI patients (Vivek \& Vikrant,
2016). A study has shown that 3 out of 14 ISRO established telemedicine centers at District hospitals (Betul, Shajapur and Khargone) in Madhya Pradesh (MP) did not have adequate electric supply (Bali et al., 2016). This problem is not limited to only MP, but affects functionality of telemedicine all over Indian subcontinent. Another study has revealed that frequent power failure occurred at four telemedicine centers (Nagthat, Kwanu, Lakhamandal and Thano) in tribal hilly areas of Uttarakhand (UK) (Suresh \& Nath, 2013). Similarly, because of power failure out of 194 teleconsulations planned with SGPGIMS Lucknow, 9 sessions at base hospital Almora and 19 sessions at base hospital Srinagar were held cancelled in hilly areas of Uttarakhand (SGPGIMS Lucknow Telemedicine Web Portal, 2019). Likewise, in HP, Wireless connectivity (WiFi and WiMax) was not possible because of high Himalayan range altitude and Terrestrial optic fiber connectivity was not possible due to cable cut (Ganapathy et al., 2016). Though ISRO has provided satellite connectivity to more than 100 hospitals, many remote villages are still to be connected to super specialty hospitals (GIM India, 2012). In addition, although, the government of HP was willing to pay three times of the salary what doctors usually get, even then doctors do not want to work in hilly Himalayan areas of HP (Ganapathy et al., 2016). Almost $80 \%$ of the telemedicine infrastructure provided by ISRO is not in use because of mismanagement (Jarosławski \& Saberwal, 2014). Undoubtedly, telemedicine has penetrated in remote areas, but its functionality is a matter of great concern. The Indian government needs to pay attention towards such emerging issues. Table 3 describes major challenges hampering use of telemedicine in India. 
Table 3: Description of various challenges and barriers towards telemedicine.

\begin{tabular}{|c|c|}
\hline $\begin{array}{c}\text { Challenges and } \\
\text { barriers }\end{array}$ & Reference \\
\hline Shortage of Electricity & Suresh \& Nath, 2013; Bali et al., 2016 \\
\hline $\begin{array}{l}\text { Unavailability of } \\
\text { Internet connectivity }\end{array}$ & $\begin{array}{l}\text { Suresh \& Nath, 2013, Ganapathy et al., } \\
\text { 2016; Hemalatha, 2015 }\end{array}$ \\
\hline Lack of Manpower & $\begin{array}{l}\text { Patnaik \& Patnaik, 2015; Suresh } \\
\text { \& Nath, 2013; Bali et al., 2016; } \\
\text { Jarosławski \& Saberwal, 2014; Apollo } \\
\text { Telemedicine Network Foundation } \\
\text { (ATNF) report } 2011\end{array}$ \\
\hline $\begin{array}{l}\text { Lack of amenities } \\
\text { supporting } \\
\text { Telemedicine }\end{array}$ & $\begin{array}{l}\text { Ganapathy et al., 2016; Bali et al., } \\
2016\end{array}$ \\
\hline Technological Issues & $\begin{array}{l}\text { Sharma et al., 2016; Suresh \& Nath, } \\
\text { 2013; Bali et al., 2016; Jarosławski \& } \\
\text { Saberwal, 2014; Gogia et al., } 2016\end{array}$ \\
\hline $\begin{array}{l}\text { Funding Associated } \\
\text { Problems }\end{array}$ & $\begin{array}{l}\text { Sharma et al., 2016; Ganapathy et al., } \\
\text { 2016; Jarosławski \& Saberwal, 2014; } \\
\text { Syed-Abdul, } 2011\end{array}$ \\
\hline $\begin{array}{l}\text { Doctor's Resistance } \\
\text { towards Telemedicine }\end{array}$ & $\begin{array}{l}\text { Patnaik \& Patnaik, 2015; Meher et al., } \\
\text { 2009; Bali et al., 2016; Arivanandan, } \\
\text { 2016; Boringi, } 2015\end{array}$ \\
\hline $\begin{array}{l}\text { Fear of Technology } \\
\text { failure }\end{array}$ & $\begin{array}{l}\text { Suresh \& Nath, 2013; Raman } \\
\text { et al.,2014; Mohanan et al., } 2016\end{array}$ \\
\hline $\begin{array}{l}\text { Lack of Awareness } \\
\text { towards Telemedicine }\end{array}$ & $\begin{array}{l}\text { Meher \& Kant, 2014; Ganapathy } \\
\text { et al., 2016; Boringi et al., } 2015\end{array}$ \\
\hline $\begin{array}{l}\text { Patient's Resistance } \\
\text { towards Telemedicine }\end{array}$ & Meher et al., 2009; Jain et al., 2015 \\
\hline
\end{tabular}

However, to resolve these challenges various initiatives are being taken by the central and state governments. Recently released National Health Policy 2017 has envisioned that, a National Digital Health Authority (NDHA) will be constituted to implement, promote and regulate the telemedicine in India (National Health Policy Government of India, 2017). Further, under National Telemedicine Network (NTN) the high-speed internet connectivity will be provided through National Knowledge Network (NKN), National Optical Fiber Network (NOFN), SATCOM (satellite communication) and terrestrial high-speed internet to boost the telemedicine services in the country (Concept Note on National Telemedicine Network (NTN); Government of India, 2019). To resolve other challenges government has initiated to provide telemedicine service in Public Private Partnership (PPP) mode (Concept Note on National Telemedicine Network (NTN)-Government of India, 2019). Telemedicine services in PPP have been effective and successful under diverse geographic and socio-economic settings in the country including inaccessible and remote areas of Himachal Pradesh (Ganapathy et al., 2016; Ganapathy, 2014; Ganapathy et al., 2018; CSC Annual Report 2015-16). Apollo Telehealth Services (ATHS), Medanta Hospital are the leading stakeholders in providing telemedicine services in PPP mode (Ganapathy et al., 2016; Ganapathy, 2014; Ganapathy et al., 2018; CSC Annual Report 2015-16).

\section{Recommendations}

- More emphasis is required on education and training of health workers, programs to promote telemedicine awareness needs to be started.

- Health workforce should be motivated and promoted for using telemedicine, and government doctors should be provided with extra emoluments for using telemedicine so that their participation in telemedicine can be enhanced.

- Issues like low bandwidth and lack of interoperability standards for software that reduce the efficiency of this technology need to be rectified along with legal, ethical and social issues.

- An integration model based on mobile App including teleconsultation services, video conferencing, patient's diagnosis details, pathology and alert system can be designed and developed to provide quality healthcare services to each and every individual through telemedicine. All healthcare services and facilities can be provided through single mobile App, this may resolve the problem of specialist's non-availability and delay in treatment.

- Telemedicine facilities in the area of neurology and neurosurgery must be deployed to extend their reach to patients residing in rural areas. A public-private partnership model may be promoted as a viable option for telemedicine to be successful.

- Awareness among both the stakeholder's viz. patients and healthcare providers may be created about telemedicine for delivery of quality healthcare services in rural and remote areas.

- Efficient revenue models should be designed for developing infrastructure, training of manpower and research and development for successful implementation and utilization of telemedicine.

\section{Limitation of the Study}

Although thorough search has been made to find out $n$ umber of telemedicine centers (Both public and private) in India (Figure 1 and Table 1), eHealth and mHealth 
systems (Table 2). However, it was difficult for authors to provide accurate number and details of telemedicine centers, eHealth systems and mHealth systems, because of the non-availability of a common source for finding out all the available information regarding the centers and systems provided in Figure 1, Table 1 and Table 2. Rather information about eHealth and Telemedicine is available in discrete form. Further, regular development and release/ opening of new telemedicine centers, eHealth platforms and mHealth platforms pose limit to find out their exact number.

\section{Ethical Approval}

Being this is a review article manuscript, obtaining ethical approval was not required. Since this is a review article and information provided herein are totally based on prepublished articles and information accessed from various health web portals, and no new empirical data were collected for writing this manuscript.

\section{Acknowledgements}

The authors sincerely thank Director National Institute of Science Technology and Development Studies (NISTADS), New Delhi for his constant support in completing this manuscript. The author also sincerely thanks to Council of Scientific and Industrial Research for providing financial assistance as Junior Research Fellowship (CSIR-JRF) to Raj Kishor Kustwar for conducting this study.

\section{Funding}

No funding is received for witting this manuscript.

\section{Competing interest}

The Authors have no competing or conflict of interest.

\section{References}

Acharya, R.V., \& Rai, J.J. (2016). Evaluation of patient and doctor perception toward the use of telemedicine in Apollo Tele Health Services, India. Journal of Family Medicine and Primary Care, 5(4), 798-803. https://doi.org/10.4103/2249-4863.201174

Apollo Telemedicine Network Foundation (ATNF) report 2011. Retrieved May 21, 2019 from http://healthmarketinnovations.org/sites/default/files/ Apollo\%20Case\%20Study.pdf
Arivanandan, M. (2016). Telemedicine Programme in Rural Health Care System of India. Indian Journal of Applied Research, 6(3), 458-461.

Bali, S., Gupta, A., Khan, A., \& Pakhare, A. (2016). Evaluation of telemedicine centres in Madhya Pradesh, Central India. Journal of Telemedicine and Telecare, 22(3), 183188. https://doi.org/10.1177/1357633X15593450

Boringi, M., Waghray, S., Lavanya, R., Babu, D.B.G., Badam, R.K., Harsha, N., Garlapati, K., \& Chavva, S. (2015). Knowledge and Awareness of Teledentistry among Dental Professionals-A Cross Sectional Study. Journal of Clinical and Diagnostic Research, 9(8), ZC41-ZC44. https://doi.org/10.7860/JCDR/2015/13303.6320

Chandwani, R.K., \& Dwivedi, Y.K. (2015). Telemedicine in India: current state, challenges and opportunities. Transforming Government: People, Process and Policy, 9(4), 393-400. https://doi.org/10.1108/TG-07-2015-0029

CSC Annual Report 2015-16. Retrieved January 10, 2019 from https://www.csc.gov.in/

Electronic Health Record (EHR) standards for India. Retrieved May 21, 2019 from https://mohfw.gov.in/ sites/default/files/17739294021483341357_1.pdf

Ganapathy, K. (2014). Telehealth in India: the Apollo contribution and an overview. Apollo Medicine, 11(3), 201-207. https://doi.org/10.1016/j.apme.2014.07.014

Ganapathy, K., Chawdhry, V., Premanand, S., Sarma, A., Chandralekha, J., Kumar, K.Y., Kumar, S., \& Guleri, S. (2016). Telemedicine in the Himalayas: Operational Challenges-A Preliminary Report. Telemedicine and e-Health, 22(10), 821-835.

https://doi.org/10.1089/tmj.2015.0249

Ganapathy, K., Alagappan, D., Rajakumar, H., Dhanapal, B., Subbu, G.R., Nukala, L., Premanand, S., Veerla, K.M., Kumar, S. \& Thaploo, V. (2018). TeleEmergency Services in the Himalayas. Telemedicine and e-Health, 22(5), 380-390. https://doi.org/10.1089/tmj.2018.0027

Gogia, S.B., Maeder, A., Mars, M., Hartvigsen, G., Basu, A., \& Abbott, P. (2016). Unintended Consequences of Tele Health and their Possible Solutions. Yearbook of Medical Informatics, 25(1) 41-46. https://doi.org/10.15265/IY-2016-012

Health and telemedicine web portals of different state governments, Government of India. Retrieved January 15, 2019 from https://www.nhp.gov.in/.

Hemalatha, S. (2015). E Learning in Health Education Feasibility, Pros and Cons. International Journal of Advanced Research in Computer Science and Software Engineering, 25(4), 372-380. 
Aravind Eye Care System Web Portal. Available on: http:// www.aravind.org/. (Last accessed on 20/05/2019).

AskApollo Web Portal. Available on: https://www.askapollo. com/. (Last accessed on 17/05/2019).

Central Drugs Standard Control Organization (CDSCO) Web Portal. Directorate General of Health Services. Ministry of Health \& Family Welfare Government of India. Available on: https://cdsco.gov.in/opencms/ opencms/en/Home/. (Last accessed on 20/05/2019).

Health Management Information System (HMIS) Web Portal. Available on: https://data.gov.in/keywords/ health-management-information-system. (Last accessed on 21/05/2019).

Doctor INSTA Web Portal. Available on: https://www. doctorinsta.com/ (Last accessed on 17/05/ 2019).

India Vision Institute Web Portal. Available on: http://www. indiavisioninstitute.org (Last accessed on 20/05/2019).

Lybrate Web Portal. Available on: (Last accessed on 17/05/2019).

mDiabetes Mobile App. Available on: http://mdiabetes.nhp. gov.in/ (Last accessed on 21/05/2019).

Integrated Health Information Platform (IHIP) Web Portal. Available on: https://www.nhp.gov.in/integrated_ health_information_program_mtl (Last accessed on 21/05/2019).

Vaccine Tracker (Indradhanush Immunisation) Mobile App. Available on: https://www.nhp.gov.in/missionindradhanush1_pg (Last accessed on 21/05/2019).

India Fights Dengue Mobile App. Available on: https:// www.nhp.gov.in/mobile-app-dengue (Last accessed on 21/05/2019).

Mera Aspatal Mobile App. Available on: https://www. nhp.gov.in/mobile-mera-aspataal (Last accessed on 21/05/2019).

Swasthya Bharat Mobile App. Available on: https://www. nhp.gov.in/nhp-swasth-bharat_pg (Last accessed on 21/05/2019).

mCessation (Quit tobacco) Mobile App. Available on: https://www.nhp.gov.in/quit-tobacco (Last accessed on 21/05/ 2019).

National Tuberculosis Elimination Programme (Nikshay Web Portal). Ministry of Health \& Family Welfare. Government of India. Available on: https://nikshay.in/ (Last accessed on 21/05/2019).

Concept Note on National Telemedicine Network (NTN), Government of India. Available on: http://nmen. in/pdf/Final $\% 20$ Concept $\% 20$ Note $\% 20$ of $\% 20$ National\%20Telemedicine\%20Network.pdf. (Last accessed on 17/05/2019).

National Telemedicine portal, Telemedicine Division, Ministry of Health and Family Welfare, Government of India. Available on: http://nmcn.in/rrcnorth/about. php (Last accessed on 20/05/ 2019).

National Organ \& Tissue Transplant Organisation (NOTTO) Web Portal. Ministry of Health \& Family Welfare. Government of India. Available on: https:// www.notto.gov.in/ (Last accessed on 20/05/2019).

KKMSG Web Portal, National Rural Health Mission. Available on: http://nrhm-mcts.nic.in/KKMSG.aspx (Last accessed on 21/05/2019).

Online Registration System Web Portal. Ministry of Electronics and Information Technology. Government of India. Available on: http://ors.gov.in/index.html. (Last accessed on 20/05/2019).

Portea Web Portal. Available on: https://www.portea.com/ (Last accessed on 17/05/2019).

Practo Web Portal. Available on: https://www.practo.com/ (Last accessed on 17/05/2019).

Televital- Enhancing the Quality of Life, Web Portal. Available on: http://www.televital.com/ (Last accessed on 17/05/2019).

ANMOL Web Portal, United Nations Children's Fund. Available on: http://unicef.in/Story/1183/ANMOLANMs-Online (Last accessed on 21/05/2019).

Venu Eye Institute \& Research Center Web Portal. Available on: http://www.venueyeinstitute.org/ content/achievements (Last accessed on 20/05/2019).

Welcare Telemedicine Web Portal. Available on: http:// welcaretelemed.com/ (Last accessed on 20/05/2019).

Jain, N., Singh, H., Koolwal, G.D., Kumar, S., \& Gupta, A. (2015). Opportunities and barriers in service delivery through mobile phones (mHealth) for Severe Mental Illnesses in Rajasthan, India: a multi-site study. Asian journal of psychiatry, 14, 31-35.

https://doi.org/10.1016/j.ajp.2015.01.008

Jarosławski, S., \& Saberwal, G. (2014). In eHealth in India today, the nature of work, the challenges and the finances: an interview-based study. BMC Medical Informatics and Decision Making, 14(1), 1-12. https://doi.org/10.1186/1472-6947-14-1

Madras Diabetes Research Foundation (MDRF). Retrieved May 20, 2019, from https://www.mdrf.in/ telemedicine.html

Mathur, P., Srivastava, S., Lalchandani, A., \& Mehta, J.L. (2017). Evolving role of telemedicine in health care delivery in India. Primary Health Care, 7, 1-6. https://doi.org/10.4172/2167-1079.1000260

Meher, S.K. \& Kant, S. (2014). Awareness and attitudes of geriatric patients towards telemedicine in India. Gerontechnology, 13(2), 262. https://doi.org/10.4017/gt.2014.13.02.391.00 
Meher, S.K., Tyagi, R.S. \& Chaudhry, T. (2009). Awareness and attitudes to telemedicine among doctors and patients in India. Journal of Telemedicine \& Telecare, 15(3), 139-141. https://doi.org/10.1258/jtt.2009.003011

Mishra, S.K., Singh, I.P., \& Chand, R.D. (2012). Current status of telemedicine network in India and future perspective. Proceedings of the Asia-Pacific Advanced Network, 32, 151-163. https://doi.org/10.7125/APAN.32.19

Mohanan, M., Babiarz, K.S., Goldhaber-Fiebert, J.D., Miller, G., \& Vera-Hernández, M. (2016). Effect of a large-scale social franchising and telemedicine program on childhood diarrhea and pneumonia outcomes in India. Health Affairs, 35(10), 1800-1809. https://doi.org/10.1377/hlthaff.2016.0481

MukhyaMantri Aarogya Kendramulu. Retrieved May 20, 2019, from http://www.euphc-ap-gov.in/Default.

MukhyaMantri e-Eye Kendram. Retrieved May 20, 2019, from http://enethraap.phc.ind.in/cmdashboard/.

National Health portal, Ministry of Health and Family Welfare, Government of India. Retrieved May 20, 2019 from https://www.nhp.gov.in/.

National Telemedicine portal, Telemedicine Division, Ministry of Health and Family Welfare, Government of India. Retrieved May 20, 2019 from http://nmon.in/.

NIMHANS Telemedicine. Retrieved May 20, 2019 from http://www.nimhans.ac.in/telemedicine

Patnaik, S., \& Patnaik, A.N. (2015). e-Health for All-is India Ready? National Journal of Community Medicine, 6(4), 633-638.

Postgraduate Institute of Medical Education \& Research (PGIMER), Chandigarh Telemedicine. Retrieved May 20, 2019 from http://pgimer.edu.in/PGIMER PORTAL/PGIMERPORTAL/Department/Global/ JSP/home_dept.jsp?CP=Eng\&deptid=d53\&B2=GO.

Raman, R., Bhojwani, D.N., \& Sharma, T. (2014). How accurate is the diagnosis of diabetic retinopathy on telescreening? The Indian scenario. Rural and Remote Health, 14(4), 2809.

Ramkumar, V., \& Selvakumar, K. (2016). Telemedicine in a tertiary care hospital in South India-A thirteen year review. Journal of the International Society for Telemedicine and eHealth, 4, 1-6.
Ray, S., Sharma, P., \& Kustwar, R.K. (2017). Scope and Challenges of Telemedicine Technology in India. Policy Perspective on Innovation and Sustainable Development. Vol IV in India S\&T Series. Syahi publication House, New Delhi India. ISSN: 978-164204-740-0. pp 156-172.

Schizophrenia Research Foundation (SCARF). Retrieved May 20, 2019, from http://www.scarfindia.org/tele-medicine/.

SGPGI telemedicine website. Retrieved May 21, 2019 from http://www.sgpgi-telemedicine.org/.

Sharma, P., Shivaram, T.R., Sharma, A. (2016). A Methodical Review of e-Health Systems Developed for Indian Healthcare Sector. Indian Journal of Science and Technology, 9(44), 1-6.

https://doi.org/10.17485/ijst/2016/v9i44/105077

Sheet, D. (2016). Toward a Comprehensive Cure: Digital information and communication technology is helping to meet health care challenges in India. IEEE Pulse, 7(6), 34-37.

https://doi.org/10.1109/MPUL.2016.2607140

Suresh, S., \& Nath, L. (2013). Challenges in managing telemedicine centers in remote tribal hilly areas of Uttarakhand. Indian Journal of Community Health, 25(4), 372-380.

Syed-Abdul, S., Scholl, J., Jian, W.S., \& Li, Y.C. (2011). Challenges and opportunities for the adoption of telemedicine in India. Journal of telemedicine and telecare, 17(6), 336-337.

https://doi.org/10.1258/jtt.2011.101210

Telemedicine National Policies, Strategies and Guidelines for implementation. Retrieved from http://www.searo. who.int/entity/health_situation_trends/events/19_ India_Country_Experience.pdf.

Total expenditure on health as a percentage of Gross Domestic Product (GDP) 2015. Retrieved January 15, 2019, from https://data.worldbank.org/indicator/ SH.XPD.CHEX.GD.ZS? year_high_desc=false.

Vivek, C., \& Vikrant, K. (2016). Tele-ECG and 24hour physician support over telephone for rural doctors can help early treatment of acute myocardial infarction in rural areas. Journal of Telemedicine and Telecare, 22(3), 203-206. https://doi. org/10.1177/1357633X15592734 


\section{旬 \\ CHITKARA}

\section{Journal of Multidisciplinary Research in Healthcare}

Chitkara University, Saraswati Kendra, SCO 160-161, Sector 9-C, Chandigarh, 160009, India

Volume 6, Issue 2

April 2020

ISSN 2393-8536

Copyright: [(C 2020 Suman Ray et al.] This is an Open Access article published in Journal of Multidisciplinary Research in Healthcare (J. Multidiscip. Res. Healthcare) by Chitkara University Publications. It is published with a Creative Commons Attribution- CC-BY 4.0 International License. This license permits unrestricted use, distribution, and reproduction in any medium, provided the original author and source are credited. 